\title{
Effect of a Peel Passion Fruit Flour (Passiflora edulis $f$. flavicarpa) Extract on the Labeling of Blood Constituents with Technetium-99m and on the Morphology of Red Blood Cells
}

\author{
Bernardo Machado Rebello ${ }^{1,2} *$, Silvana Ramos Farias Moreno ${ }^{2,3}$, Camila Godinho \\ Ribeiro $^{1,2}$, Rosane de Figueiredo Neves ${ }^{1,2}$, Adenilson de Souza da Fonseca ${ }^{1}$, Luis Querino de \\ Araújo Caldas $^{3}$, Mario Bernardo-Filho ${ }^{1,2}$ and Aldo da Cunha Medeiros ${ }^{1}$ \\ ${ }^{1}$ Programa de Pós-Graduação em Ciências da Saúde; Universidade Federal do Rio Grande do Norte; Av. Gal. \\ Gustavo Cordeiro de farias, s/n; 59010-180; rebellobm@uol.com.br; Natal - RN - Brasil. ${ }^{2}$ Departamento de \\ Biofísica e Biometria; Instituto de Biologia Roberto Alcântara Gomes; Universidade do Estado do Rio de Janeiro; \\ Av. 28 de Setembro, 87; 20551-030; Rio de Janeiro - RJ - Brasil. ${ }^{3}$ Programa de Pós-Graduação em Ciências \\ Médicas; Universidade Federal Fluminense; Niterói - RJ - Brasil
}

\begin{abstract}
Passiflora edulis f. flavicarpa (maracuja) is a fruit consumed in Brazil and worldwide. Blood constituents labeled with technetium-99m $(99 \mathrm{mTc})$ are used in nuclear medicine. The effect of $P$. flavicarpa extract on the radiolabeling of blood constituents and on red blood cells morphology was evaluated. Blood samples from Wistar rats was incubated with P. flavicarpa extract. After that, the labeling of blood constituents with 99mTc was carried out. Samples of plasma and blood cells were precipitated with trichloroacetic acid to isolate the soluble and insoluble fractions of plasma and blood cells. The radioactivity in each fractions was counted and the percentage of radioactivity was determined. Blood smears were also prepared to morphological evaluation and perimeter/area ratio determination. P. flavicarpa extract altered $(p<0.05)$ the fixation of ${ }^{99 m}$ Tc on plasma proteins and the perimeter/area ratio of red blood cells. Substances present in P. flavicarpa extract could affect the labeling of blood constituents with ${ }^{99 m}$ Tc acting in specific targets as membrane of red blood cells.
\end{abstract}

Key words: Labeling, Blood, Passiflora edulis f. flavicarpa, Radiobiocomplexes, technetium-99m

\section{INTRODUCTION}

Passion fruit, Passiflora edulis f. flavicarpa ( $P$. flavicarpa) is a fruit widely consumed worldwide and in Brazil is commonly known as "maracujá". The pulp of this fruit contains ascorbic acid and carotenoids (Talcoot et al., 2003). The passion fruit peel corresponds to $60 \%$ of the fruit and it contains pectin (21.5\%), tryptophan, grax acid and sulphured aminoacids (Guertzenstein, 1998). It has been reported some benefic effects of the $P$. flavicarpa flour in Wistar diabetic rats, such as cholesterol level reduction, increased glucose tolerance, prolonging gastric-emptying half-time, (Guertzenstein, 1998) increased protein metabolism (Pirman et al., 2007).

There are also studies in human suggesting an effect of pectin in reduction of cholesterol

\footnotetext{
* Author for correspondence
} 
(Guertzenstein, 1998; Schwiezer et al., 1991), glucose blood levels (Schwartz et al., 1988) and glucose absorption in human intestine (Fuse et al., 1989).

Technetium-99m $\left({ }^{99 \mathrm{~m}} \mathrm{Tc}\right)$ is the most utilized radionuclide in nuclear medicine to obtain single photon emission computed tomography (SPECT). Its wide use in nuclear medicine is due to its optimal characteristics (half-life of 6h, gamma ray energy of $140 \mathrm{keV}$, easily obtained from a $99 \mathrm{Mo} / 99 \mathrm{mTc}$ generator, minimal dose to the patient and negligible environmental impact) (Hladik III et al,. 1987). The chemical form of the ${ }^{99 \mathrm{~m}} \mathrm{Tc}$ obtained from the generator is sodium pertechnetate $\left(\mathrm{Na}^{99 \mathrm{~m}} \mathrm{TcO}_{4}\right)$. This ion has an oxidation number +7 , which is practilly nonreactive and can not label any compound (Saha, 2004). The labeling of some biocomplexes (Moreno et al., 2004; Bernardo-Filho et al., 2005) needs a reducing agent and stannous chloride $\left(\mathrm{SnCl}_{2}\right)$ is the most utilized with this purpose (Saha, 2004).

Red blood cells (RBC) labeled with ${ }^{99 \mathrm{~m}} \mathrm{Tc}$ are used in research (Moreno et al., 2004; Bernardo-Filho et al., 2005; Santos-Filho et al., 2005, Freitas et al., 2007) and in many procedures of nuclear medicine, including studies for spleen localization, gastrointestinal bleeding sites, blood cells mass localization, cardiovascular system studies, placental studies (Saha, 2004).

Plasma proteins (macroaggregated albumin) can be labeled with $99 \mathrm{mTc}$ and it can be used for lung perfusion imaging (Saha, 2004).

Sequential steps of the intracellular labeling process of the RBC include: (i) transmembrane transport of stannous and pertechnetate ions into internal compartment of RBC; (ii) reduction of ${ }^{99 \mathrm{~m}} \mathrm{Tc}\left({ }^{99 \mathrm{~m}} \mathrm{TcO}_{4}\right)$ by the $\mathrm{SnCl}_{2}$ and (iv) binding of the reduced ${ }^{99 \mathrm{~m}} \mathrm{Tc}$ to hemoglobin (Callahan and Rabito, 1990).

Due the importance of the labeled blood constituents in nuclear medicine, the aim of this study was to evaluate the effect of a $P$. flavicarpa extract on the labeling of blood constituents with $99 \mathrm{mTc}$ and on the morphology of red blood cells using an in vitro experimental model.

\section{MATERIALS AND METHODS}

Wistar male rats (250-300g, 3-4 months) were obtained from the Laboratório de Radiofarmácia Experimental (Departamento de Biofísica e Biometria, Universidade do Estado do Rio de Janeiro, RJ, Brazil). They were maintained under controlled room conditions $\left(22 \pm 5^{\circ} \mathrm{C}, 12 \mathrm{~h}\right.$ of light/dark cycle), water and normal diet (ad libitum). Experiments were conducted in accordance with the Department Committee of Animal Care of this University (Protocol number CEA/133/2006).

A commercial of Peel Passion Fruit Flour was obtained from A.S.S. Neto's Alimentos LTDA., Rio de Janeiro, Brazil, (Lot 0001415).

In the preparation of the extract, $0.5 \mathrm{~g}$ of the flour was diluted to $10 \mathrm{~mL}$ in saline solution $(0.9 \%$ $\mathrm{NaCl}$ ) and shacked (2 minutes). The preparation was centrifuged (clinical centrifuge, 5 minutes, $1500 \mathrm{rpm}$ ). The supernatant solution was retired and considered $100 \%(50 \mathrm{mg} / \mathrm{mL})$ solution. The concentrations $25 \mathrm{mg} / \mathrm{mL}, 12.5 \mathrm{mg} / \mathrm{mL}, 6.25 \mathrm{mg} / \mathrm{mL}$ and $3.12 \mathrm{mg} / \mathrm{mL}$ were also obtained with successive dilutions in saline solution.

A spectrophotometric analysis (Analyser, 800M, São Paulo, Brazil) of $P$. flavicarpa extract was carried out. The absorbance at $480 \mathrm{~nm}$ was considered the marker of the quality control of this extract. All the prepared extracts to be used in the experiments must have the optical density close to 0.18 (Fig. 1) to be used in the experiments.

Blood samples $(0.5 \mathrm{~mL})$ were incubated with $100 \mu \mathrm{L}$ of different concentrations of $P$. flavicarpa extract for 60 minutes at room temperature. As control, samples of heparinized whole blood were incubated with $0.9 \% \mathrm{NaCl}$ solution. After this period of time, $0.5 \mathrm{~mL}$ of stannous chloride (Sigma Chemical Co., USA) $(1.2 \mu \mathrm{g} / \mathrm{mL})$ solution (freshly prepared) were added and incubated for more 60 minutes. Then, $0.1 \mathrm{~mL}(3.7 \mathrm{MBq})$ of $99 \mathrm{mTc}$, as sodium pertechnetate, (Instituto de Pesquisas Energéticas e Nucleares, Comissão Nacional de Energia Nuclear, São Paulo, Brazil) was added and the incubation continued for more 10 minutes. These samples were centrifuged and plasma $(\mathrm{P})$ and cells $(B C)$ were separated. Samples $(20 \mu \mathrm{L})$ of $\mathrm{P}$ and $\mathrm{BC}$ were also precipitated with $1 \mathrm{ml}$ of $5 \%$ trichloracetic acid (TCA) and insoluble (IF) and soluble fractions (SF) isolated. The radioactivity of the samples was determined in a well counter (Automatic Gamma Counter, C5002, Packard, USA). After that, the percentage of radioactivity 
(\%ATI) was calculated as described elsewhere (Bernardo-Filho et al. 1983).

The morphometry study of the red blood cells was also performed with the samples of blood incubated with $P$. flavicarpa extract (all concentrations). One drop of each sample was smeared in glass slides (5 slides for each sample) and the May-Grünwald-Giemsa method was performed (Junqueira and Carneiro, 2004). The smears were evaluated under a light microscope of clear field (Eclipse E $400^{\mathrm{TM}}$ ), in the immersion objective (100x), with photographer ocular. Quantification of the data was realized by Software image pro plus (media Cyberbetics)

Statistical analysis (Kruskal-Wallis with post-test Dunns, $\mathrm{p}<0.05$ ) was used to compare the experimental data with the controls.

\section{RESULTS}

The Fig. 1 shows the absorbance spectrum of a Passiflora edulis $f$. flavicarpa extract. The data in this figure indicate that the main absorbance peak (0.18) of this P. flavicarpa extract occurs at 480 nm.

Table 1 shows the effect of the $P$. flavicarpa extract on the distribution of the radioactivity in plasma and cellular compartments. The results indicate no significant $(p>0.05)$ alteration of the distribution of ${ }^{99 \mathrm{~m}} \mathrm{Tc}$ between plasma and cellular compartments.

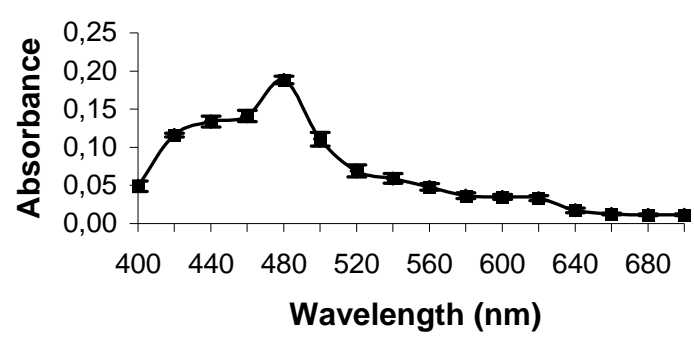

Figure 1 - The absorption spectrum of a P flavicarpa extract

Table 1 - Effect of $P$. flavicarpa extract on the distribution of radioactivity between plasma and cellular compartments of the whole blood.

\begin{tabular}{lcc}
\hline P. flavicarpa $(\mathbf{m g} / \mathbf{m l})$ & $\begin{array}{c}\text { ATI\% } \\
\text { Plasma }\end{array}$ & $\begin{array}{c}\text { ATI\% } \\
\text { Blood Cells }\end{array}$ \\
\hline Control & $4.48 \pm 1.79$ & $95.52 \pm 1.79$ \\
3.0 & $3.19 \pm 2.30$ & $96.81 \pm 2.30$ \\
6.0 & $2.02 \pm 0.48$ & $97.98 \pm 0.48$ \\
12 & $2.84 \pm 1.68$ & $97.16 \pm 1.68$ \\
25 & $2.61 \pm 2.95$ & $97.39 \pm 2.95$ \\
50 & $4.17 \pm 3.28$ & $95.83 \pm 3.28$ \\
\hline
\end{tabular}

Blood samples were incubated with P. flavicarpa extract for 60 minutes and the radiolabeling procedure was carried out. The radioactivity of plasma $(\mathrm{P})$ and cells $(\mathrm{BC})$ was determined and the percentage of radioactivity (\%ATI) was calculated.

Table 2 shows the fixation of the radioactivity on the plasma proteins. The results indicate that there is a significant decrease $(p<0.05)$ of the fixation of ${ }^{99 \mathrm{~m}} \mathrm{Tc}$ on the insoluble fraction of plasma at the highest concentrations.

Table 3 shows the fixation of the radioactivity on blood cell proteins. The results indicates no significant $(\mathrm{p}>0.05)$ alteration on the fixation of ${ }^{99 \mathrm{~m}} \mathrm{Tc}$ on soluble and insoluble fractions of the blood cells.
The qualitative analysis of the shape of red blood cells from blood samples treated with $P$. flavicarpa extract has shown important morphological alterations in the red blood cells. Some blood cells have presented spikes on the membrane (Fig. 3). These alterations were not found when blood samples were incubated with $0.9 \% \mathrm{NaCl}$ solution, which presented cells with a normal and characteristic shape (Fig. 2). 
A morphometric parameter (perimeter/area ratio) of the red blood cells was also significantly altered $(\mathrm{p}<0.05)$ when blood samples were treated with $P$. flavicarpa extract (Table 4).

Table 2 - Effect of P. flavicarpa extract treatment on the fixation of radioactivity on the plasma proteins.

\begin{tabular}{lcc}
\hline P. flavicarpa $(\mathbf{m g} / \mathbf{m l})$ & $\begin{array}{c}\text { ATI\% } \\
\text { Insoluble Fraction }\end{array}$ & $\begin{array}{c}\text { ATI\% } \\
\text { Soluble Fraction }\end{array}$ \\
\hline Control & $72.77 \pm 3.40$ & $27.23 \pm 3.40$ \\
3.0 & $72.37 \pm 1.59$ & $27.63 \pm 1.59$ \\
6.0 & $67.36 \pm 5.61$ & $32.64 \pm 5.61$ \\
12 & $67.93 \pm 1.79$ & $32.07 \pm 1.79$ \\
25 & $* 64.06 \pm 3.14$ & $35.94 \pm 3.14$ \\
50 & $* 53.98 \pm 6.78$ & $46.02 \pm 6.78$ \\
\hline
\end{tabular}

Blood samples were incubated for 60 minutes with $P$. flavicarpa extract and the radiolabeling procedure was carried out. Aliquots of plasma were precipitated with TCA to isolate the soluble and insoluble fractions of plasma. The radioactivity in each fraction was determined and the percentage of radioactivity (\%ATI) was calculated. $(*) \mathrm{p}<0.05$ when compared with control group.

Table 3 - Effect of $P$. flavicarpa extract treatment on the fixation of radioactivity on the blood cell proteins.

\section{P. flavicarpa (mg/ml)}

Control

3.0

6.0

12

25

50
ATI\%

Insoluble Fraction

$92.82 \pm 1.98$

$93.29 \pm 1.46$

$93.46 \pm 0.87$

$93.43 \pm 1.30$

$92.99 \pm 1.63$

$90.61 \pm 2.84$

\section{ATI\%}

\section{Soluble Fraction}

$7.18 \pm 1.98$

$6.71 \pm 1.46$

$6.54 \pm 0.87$

$6.57 \pm 1.30$

$7.01 \pm 1.63$

$9.39 \pm 2.84$

Blood samples were incubated with $P$. flavicarpa extract for 60 minutes and the radiolabeling procedure was carried out. Aliquots of blood cells were precipitated with TCA to isolate the soluble and insoluble fractions of blood cells. The radioactivity in each fraction was determined and the percentage of radioactivity (\%ATI) was calculated.

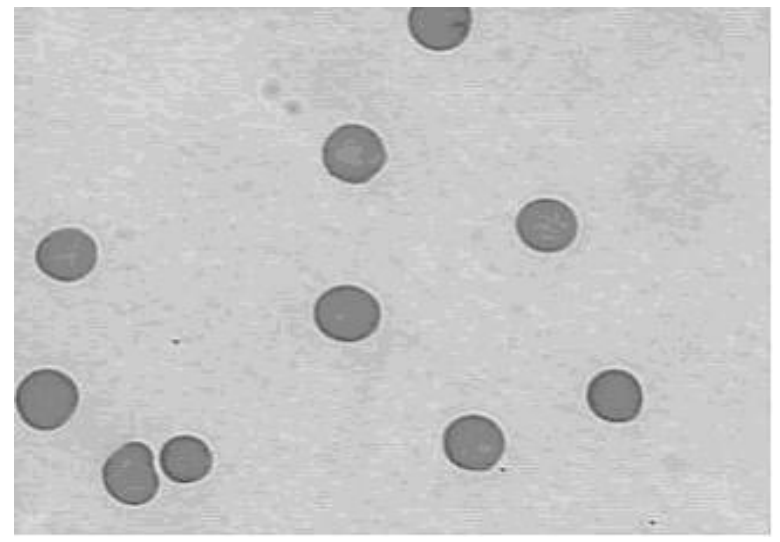

Figure 2 - Photomicrography of blood smears from blood samples treated with $\mathrm{NaCl} 0.9 \%$. Blood samples incubated with saline solution for 60 minutes. After that, smears were prepared, dried, fixed and staining. Morphology of red blood cells was evaluated under light microscopy (x1000) 


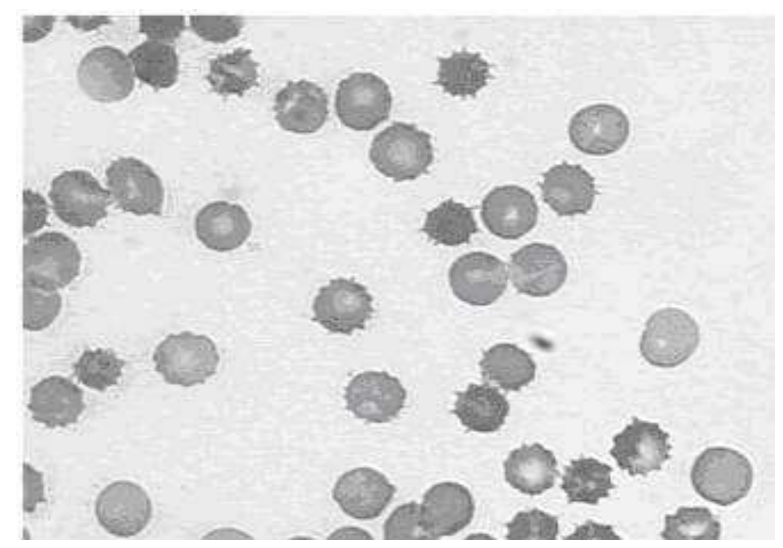

Figure 3 - Photomicrography of blood smears from blood treated with $P$. flavicarpa extract. Blood samples were incubated with P. flavicarpa extract $(50 \mathrm{mg} / \mathrm{ml})$ for 60 minutes. After that, smears were prepared, dried, fixed and staining. Morphology of red blood cells was evaluated under light microscopy (x1000)

Table 4 - The perimeter/area ratio of RBC incubated with PPFF and labeled with ${ }^{99 \mathrm{~m}} \mathrm{Tc}$.

\begin{tabular}{cc} 
P. flavicarpa $(\mathbf{m g} / \mathbf{m l})$ & $\begin{array}{c}\text { Perimeter/area } \\
\text { Ratio }(\mathbf{1} / \boldsymbol{\mu m})\end{array}$ \\
\hline 0.0 & $0.42 \pm 0.01$ \\
3.0 & $0.46 \pm 0.01$ \\
6.0 & $0.42 \pm 0.01$ \\
12 & $0.44 \pm 0.01$ \\
25 & $* 0.65 \pm 0.04$ \\
50 & $* 0.70 \pm 0.09$ \\
\hline
\end{tabular}

Blood samples were incubated with P. flavicarpa extract for 60 minutes. After that, smears were prepared, dried, fixed and staining. Morphology of red blood cells was evaluated under light microscopy. After image caption, measurement of perimeter and area was performed and the perimeter/area ratio was determined.

\section{DISCUSSION}

Although there is great variety of medicinal plants, there is not so much data relating natural products correct identification of their chemical composition, collateral effects, therapeutic properties and some biological properties (Messina, 2006). The radiolabeling of blood constituents has a great importance in nuclear medicine (Saha, 2004). Some authors have suggested that drugs could alter the radiolabeling of blood constituents (Moreno et al., 2002; Abreu et al., 2006; Silva et al., 2006), as well as, promote morphological alterations on the erythrocyte membrane (Braga et al., 2000; Oliveira et al., 2002; Oliveira et al., 2003; Santos-Filho et al., 2004; Moreno et al., 2004). Other studies report that some natural products could not interfere on the radiolabeling of blood constituents (Diré et al.,
2004; Fernandez et al., 2005) and could not modify the morphology of the red blood cells (Fernandez et al., 2005).

The analysis of the our results indicates that $P$. flavicarpa extract decreased the fixation of ${ }^{99 \mathrm{~m}} \mathrm{Tc}$ on plasma proteins and did not alter the labeling of blood cells with ${ }^{99 \mathrm{~m}} \mathrm{Tc}$. It should be possible that the chemical compounds in P. flavicarpa extract could compete with the ${ }^{99 \mathrm{~m}} \mathrm{Tc}$ (pertechnetate) and/or stannous ions for the binding sites of the plasma proteins decreasing the fixation of ${ }^{99 \mathrm{~m}} \mathrm{Tc}$ on plasma proteins.

The morphological analysis showed an increase of the perimeter/area ratio of red blood cells from blood samples treated with $P$. flavicarpa extract $(50 \mathrm{mg} / \mathrm{ml})$. Similar alterations were obtained when blood samples were treated with $25 \mathrm{mg} / \mathrm{ml}$ (data not shown). It could be suggested that some substances present in the $P$. flavicarpa extract 
could promote morphological alterations on the membrane of red blood cells as shown in the Fig. 3. Alterations on the erythrocyte membrane have also been reported to other extracts as Tobacco (Braga et al., 2000), Maytenus ilicifolia (Oliveira et al., 2000), Paulinia cupana (Oliveira et al., 2002), Coffea Arabica (Oliveira et al., 2003), Fucus vesiculosus (Oliveira et al., 2003) and Ginkgo biloba (Moreno et al., 2004). In these studies when the morphological alterations occurred, the red blood cells labeling with ${ }^{99 \mathrm{~m}} \mathrm{Tc}$ was also altered by the extracts. P. flavicarpa extract is capable to modify the erythrocyte membrane morphology, but is not capable to modify the labeling of blood cells. It may possible that the morphological alterations produced by chemical compounds in $P$. flavicarpa extract on the membrane red blood cells could not interfere on the ions transport mechanism into the cell. In consequence the labeling of the blood cells would be not altered.

\section{ACKNOWLEDGEMENTS}

We are grateful for the biologist Mario Pereira (UERJ) for his technical support and to Mr. Carlos Brown Scavarda (B. A., University of Michigan) for the English language revision. Financial support: CNPq, CAPES and UERJ.

\section{RESUMO}

Passiflora edulis f. flavicarpa (maracujá) é um fruto consumido no Brasil e no mundo. $\mathrm{O}$ efeito de um extrato de farinha da casca de maracujá na marcação dos constituintes sangüíneos com tecnécio-99m e na morfologia de hemácias foi avaliado. Amostras de sangue de ratos Wistar, foram incubadas com extrato de P. flavicarpa. Em seguida, o procedimento de marcação de constituintes sangüíneos com Tc-99m foi realizado. Amostras de plasma e células sanguiíneas foram separadas e alíquotas destas frações foram precipitadas com ácido tricloroacético para isolamento das frações solúvel e insolúvel do plasma e das células sangüíneas. A radiatividade em cada fração foi contada a porcentagem de radioatividade (\%ATI) foi calculada. Distensões sangüíneas foram também preparadas para avaliação morfológica e da relação perímetro/área de hemácias. O extrato de P. flavicarpa alterou a fixação do ${ }^{99 \mathrm{~m}} \mathrm{Tc}$ nas proteínas plasmáticas e a relação perímetro/área das hemácias. Substâncias presentes no extrato de P. flavicarpa poderiam afetar a marcação de constituintes sangüíneos com ${ }^{99 \mathrm{~m}} \mathrm{Tc}$ atuando em alvos específicos, como a membrana das hemácias.

\section{REFERENCES}

Abreu, P. R. C, Almeida, M. C., Bernardo, R. M., Bernardo, L. C., Brito, L. C., Garcia, E. A. C., Fonseca, A. S., Bernardo-Filho, M. (2006), Guava extract (Psidium gaujava) alters the labeling of blood constituents with technetium-99m. J. Zheijiang Univ. SCIENCE B., 7,429-435.

Bernardo-Filho, M., Moura, I. N. S., Boasquevisque, E. M. (1983), 99m technetium - labeled red blood cells "in vitro". Arq. Biol. Technol., 4,455-461.

Bernardo-Filho, M., Nogueira, F. J., Sturm, J. A., Boasquevisque, E. M. (1990), Plasma proteins labelling with ${ }^{99 m}$ technetium. Arq. Biol. Tecnol., 4,811-817.

Bernardo-Filho, M., Santos-Filho, S. D., Moura, E. G., Maiworn, A. I., Orlando, M. M. C., Penas, M. E., Cardoso, V.N., Bernardo, L.C., Brito, L.C. (2005), Drug interaction with radiopharmaceuticlas: a review. Braz. Arch. Biol. Technol., 48,13-27.

Berne, R. M., Levy, M. N. (2000), Fisiologia. Guanabara Koogan: Rio de Janeiro.

Braga, A. C. S., Oliveira, M. B. N., Feliciano, G. D., Reininger, I. W., Oliveira, J. F., Silva, C. R., Bernardo-Filho, M. (2000), The effects of drugs on the labeling of blood elements with tecnetium-99m. Curr. Pharm. Des., 6,1179-1191.

Callahan, R. J., Rabito, C. A. (1990), Radiolabeling of erythrocytes with technetium-99m: role of band-3 protein in the transport of pertechnetate across the cell membrane. J. Nucl. Med., 31,2004-2008.

Diré, G., Lima, E. A. C., Gomes, M. L., Moreno, S., Marques, M. T. Q., Jales, R. L., Caldeia-de-Araújo, A., Bernardo-Filho, M. (2004), An in vitro study of a natural product (chayote): an analysis on the labeling of blood components with technetium-99m and on the morphology of 20DNA. J. Food Technol., 2,7175.

Fernandes, J. F. O., Frydman, J. N. G., Santos-Filho, S., Bernardo-Filho, M. (2005), An aqueous extract of Pfaffia sp. Does not alter the labeling of blood constituents with technetium-99m and the morphology of red blood cells. Braz. J. Pharmacogn., 15,126-132. 
Freitas, R. S., Moreno, S. R. F., Lima-Filho, G. L., Fonseca, A. S., Bernardo-Filho, M. (2007), Effect of a comercial extract of Paulinia cupana (guaraná) on the biding of $99 \mathrm{mTc}$-DMSA on blood constituents: An in vivo study. Appl. Radiat. Isot., 65,528-533.

Fuse, K., Bamba, T., Hosoda, S. (1989). Effects of pectin on fatty acid and glucose absorption and on thickness of unstirred water layer in rat and human intestine. Dig. Dis. Sci., 34,1109-1116.

Guertzenstein, S. M. J. (1998), Caracterização da farinha da casca de maracujá (Passiflora edulis $f$. flavicarpa) cv. Amarelo como fonte de fibra solúvel para alimentação humana. MD Thesis, Universidade Federal do Rio de Janeiro, Rio de Janeiro, Brazil.

Gutfilen, B., Boasquevisque, E. M., Bernardo-Filho, M. (1992), Calcium channels lockers: interference on red blood cells and plasma proteins labeling with $99 \mathrm{mTc}$. Rev. Esp. Med. Nucl., 11,195-199.

Hladik III, W. B., Saha, G. B., Study, K. T. (1987), Essentials of nuclear medicine science. Williams and Wilkins, Baltimore, London.

Junqueira, L. C., Carneiro, J. (2004), Histologia Básica. Guanabara Koogan, Rio de Janeiro.

Messina, B. A. (2006), Herbal supplements: facts and myths - talking to your patients about herbal supplements. J. Perianesth. Nurs., 21,268-78.

Moreno, S. R. F., Diré, G. F., Freitas, R. S., Farah, M. B., Lima-Filho, G. L., Rocha, K. E., Jales, R. L. C., Bernardo-Filho, M. (2002), Effect of Ginkgo biloba on the labeling of red blood elements with technetium-99m: in vitro study. Rev. Bras. Farmacog., 12,62-63.

Moreno, S. R. F., Rocha, E. K., Pereira, M., MandarimLacerda, C., Freitas, R. S., Nascimento, A. L. R., Carvalho, J. J., Lima-Filho, G. L., Diré, G., Lima, E. A. C., Bernardo-Filho, M. (2004), Ginkgo biloba extract: experimental model to evaluate its action on the labeling of blood elements with Technetium-99m and on the morphometry of red blood cells. Pakistan J. Nutr., 3,68-71.

Oliveira, J. F., Braga, A. C. S., Oliveira, M. B., Ávila, A. S., Caldeira-de-Araújo, A., Cardoso, V. N., Bezerra, R. J. A., Bernardo-Filho, M. (2000), Assessment of the effect of Maytenus ilicifolia (Espinheira-santa) extract on the labeling of red blood cells and plasma proteins with technetium-99m. $J$. Ethnopharmacol., 72,179-184.

Oliveira, J. F., Ávila, A. S., Braga, A. C. S., Oliveira, M. B. N., Boasquevisque, E. M., Jales, R. L., Cardoso, V. N., Bernardo-Filho, M. (2002), Effect of extract of medicinal plants on the labeling of blood elements with technetium-99m and on the morphology of red blood cells: I - a study with Paulínia cupana. Fitoterapia, 73,305-312.
Oliveira, J. F., Oliveira, M. B. N., Ávila, A. S., Braga, A. C. S., Catanho, M. T. J., Jales, R. L. C., Cardoso, V. N., Bernardo-Filho, M. (2003), Assessment of the effect of Fucus vesiculosus extract on the labeling of blood constituents with technetium-99m and the histological modifications on the shape of the red blood cells. Food Chem. Tox., 41,15-20.

Oliveira, J. F., Santos-Filho, S. D., Catanho, M. T. J., Srivastava, S. C., Lima-Filho, G., Bernardo-Filho, M. (2003), Effect of extract medicinal plant $n$ the labeling of blood elements with technetium-99m and on the morphology of red blood cells (RBC): toxicological action of roast coffee beans (Coffea arabica). Indian J. Nucl. Med., 18,52-56.

Pirman, T., Ribeyre, M. C., Mosoni, L., Remond, D., Vreel, M., Salobir, J., Patureau Mirand, P. (2007), Dietary pectin stimulates protein metabolism in the digestive tract. Nutrition, 23, 69-75.

Saha, G. B. (2004), Fundamentals of Nuclear Pharmacy. New York: Springer-Verlag.

Santos-Filho, S. D., Diré, G., Lima, E., Oliveira, M. N., Bernardo-Filho, M. (2004), Effect of Mentha crispa (mint) extract on the labeling of blood elements with technetium-99m: a possible evaluation of free radicals. J. Biol. Sci., 4, 266-270.

Santos-Filho, S. D., Bernardo-Filho, M. (2005) Effect of Hypericum perforatum extract in vitro labeling of blood elements with technetium-99m and on biovailability of sodium pertechentate in Wistar rats. Acta Cir. Bras., 1, 76-80.

Schwartz, S. E., Levine, R. A., Weinstock, R. S., Petokas, S., Mills, C. A., Thomas, F. D. (1988), Sustained pectin ingestion: effect on gastric emptying and glucose tolerance in non-dependent diabetic patients. Am. J. Clin. Nutr., 48, 1413-1417.

Schweizer, T. F., Wursch, P. (1991), The physiological and nutrition importance of dietary fibre. Experientia, 47, 181-186.

Silva, A. L. C., Moreno, S. R. F., Rebello, B., Florentino, D., Diré, G., Carvalho, J. J., Nascimento, A. N., Honeicut, H., Santos-Filho, S., Oliveira, S. A., Rocha, E.K., Bernardo-Filho, M., Caldas, L. Q. A. (2006). Uncaria tomentosa extract: evaluation of effects on the in vitro and in vivo labeling of blood constituents with technetium-99m. Ed Ulderico Mazzi. Technetium, Rhenium and Other Metals in Chemistry and Nuclear Medicine 7, Padova, pp:547548.

Talcoot, S. T., Percival, S. S., Pittet-Moore, J., Celoria, A. C. (2003), Phytochemical composition and antioxidant stability of fortified yellow passion fruit (Passifora edulis). J. Agric. Food Chem., 51, 935941.

Received: July 22, 2007; Revised: August 08, 2007; Accepted: September 11, 2007. 
PÁGINA

EM

BRANCO 